\title{
Couture of the Corpse: \\ Fashion, Class, Time, and the Undead in The Hunger
}

\author{
Kwasu David Tembo \\ Independent Researcher - tembo.kwasu@gmail.com
}

\begin{abstract}
When viewed from the lens of couture and class, the contemporary portrayal of the vampire as iconic in both sociopolitical and aesthetic spheres, and as icons of various subaltern, outsider, or what I call 'demimondeur' lifestyles, subcultures, and their attendant styles/fashions, offers an interesting analytical frame through which to examine the dialogic relationship between ideology, time, fashion, and class. Referring to Marxist thought concerning vampire capitalism and time, this chapter will discuss the issues and

debates surrounding the portrayal of the figure of the vampire as what I will theorize to be a 'pure consumer', sociopolitical elite, and sociopolitical outsider, and its figuration of both the atemporality and spuriousness of ideology in The Hunger (1983). Referring to the Bauhaus post-punk couture or style of the undead in the film, the methodology of this paper will be to perform a close reading of the film as a case study, focussing on its engagement with the sociopolitics, cultures, and phenomena of wealth, style, privilege, and time(lessnes).
\end{abstract}

Keywords: Vampire, fashion, The Hunger, undead chic, corpse couture.

\section{A Alta-Costura do Cadáver: Moda, Classe, Tempo, e os Mortos-Vivos em Fome de Viver}

\section{Resumo}

Quando visto através das lentes da alta costura e do sistema de classes, o retrato contemporâneo do vampiro como icónico tanto na esfera sociopolítica como na estética, e como ícones de vários estilos de vida subalternos, exteriores, ou aquilo a que chamo estilos de vida "demimondeur", subculturas e os estilos/modas que os acompanham, oferece um quadro analítico interessante através do qual se pode examinar a relação dialógica entre ideologia, tempo, moda e classe. Referindo-se ao pensamento marxista sobre o capitalismo vampírico na sua relação com o tempo, este capítulo discutirá as questões e debates em torno do retrato da figura do vampiro como o que teorizarei ser um "puro consumidor", simultaneamente elite sociopolítica e forasteiro sociopolítico, e a sua figuração tanto da atemporalidade como da 
espúria da ideologia em Fome de Viver (1983). Referindo-se à couture pós-punk Bauhaus ou ao estilo dos mortos-vivos do filme, a metodologia deste trabalho será a de realizar uma leitura atenta do filme como um estudo de caso, focando o seu envolvimento com dimensões sociopolíticas e culturais, e com os fenómenos de riqueza, estilo, privilégio e tempo (atemporalidade).

Palavras-chave: Vampiro, moda, Fome de Viver, morto-vivo chic, couture de cadáver.

\section{Figure 1}

The Saturnine Sophistication of Miriam and John Blaylock in Tony Scott's The Hunger (1983).

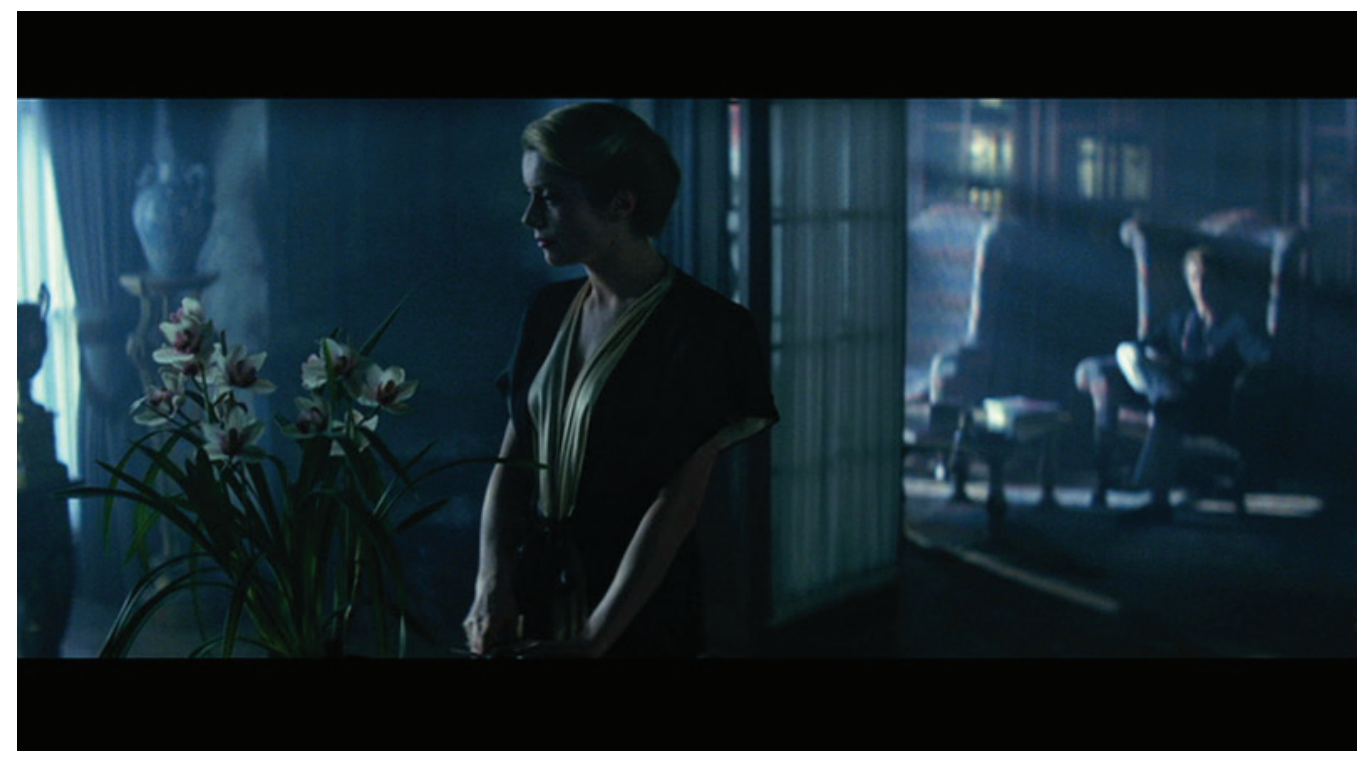

\section{I. “THE BLUE AND THE DIM AND THE DARK CLOTHS OF NIGHT": ON THE NATURE OF VAMPIRES}

We cannot begin to theorize the relationship between vampire fashion and class without first offering a theorization of the figure of the vampire itself more broadly. In the history of global visual and popular culture, and Western visual and popular culture more specifically, the figure of the vampire has emerged and re-emerged 
in polyvalent and manifold combinations, appearing in every media from print to screen, every genre from comedy to science fiction, every demographic from toddler to avant-garde: from Bram Stoker's Dracula (1897), F. W. Murnau's Nosferatu (1922), Richard Matheson's I Am Legend (1954), Werner Herzog's Nosferatu (1979), Joel Schumaker's The Lost Boys (1987), Katheryn Bigelow's Near Dark (1987), Francis Ford Coppola's Dracula (1992), Joss Whedon's Buffyverse (1997-2004), Stephen Norrington's Blade (1998) and later in Guillermo Del Toro's Blade 2 (2002), Tomas Alfredson's Let The Right One In (2008), Park Chan-Wook's Thirst (2009), The Spierig Brothers' Daybreakers (2009), to the cinematic Twilight Saga (2008-2012). A recurrent theme in vampire movies pertains to the issues and debates surrounding the supernatural endowment of temporal capital and the socioeconomic, sociopolitical, cultural, and ideological advantages and deprivations that result therefrom. Interestingly, fashion is often an ostensible symbol that demarcates the particular socioeconomic status of the hominus nocturna of the aforementioned examples and beyond.

When viewed through the lens of couture and class, the contemporary portrayal of the vampire as iconic in both sociopolitical and aesthetic spheres, and as icons of various of what I call 'demimondeur' lifestyles, subcultures, and their attendant styles/ fashions, offers an interesting analytical frame through which to examine the dialogic relationship between capitalist ideology, time, fashion, and class. Be it as seemingly paradoxical Other aristocracy in texts like Underworld (2003) and Daybreakers (2010), or as tattered representations of plague hysteria seen in Blade 2 (2002) and/ or immigrant fear in Nosferatu (1922), the aesthetic depiction of the vampire in $20^{\text {th }}$ and $21^{\text {st }}$ century film and television has always-already been intimately engaged with issues and debates surrounding class. Beyond the vampire's traditional Gothic chic seen in texts such as Interview with a Vampire (1994) and Dracula (1931), vampires have been portrayed, aesthetically, in myriad ways: in the style of upper echelon sophisticates in texts such as Da Sweet Blood of Jesus (2014), Hillbilly chic in From Dusk Till Dawn (1996), Bohemian/Hippy chic in Only Lovers Left Alive (2013), Yuppy/ Hipster chic in Kiss of the Damned (2012), Single Mom chic in Byzantium (2012), and Suburban chic in The Twilight Saga (2008-2012). Referring primarily to Marxist thought concerning vampire capitalism and time, this article will discuss the issues and debates surrounding the portrayal of the figure of the vampire as what I will theorize to be a 'pure consumer', socioeconomic elite, and socioeconomic outsider, and its figuration of both the atemporality and spuriousness of ideology in The Hunger (1983). To do so, this paper will be to perform a close reading of the film as a case 
study, focussing on its engagement with the socioeconomics, cultures, and phenomena of wealth, style, privilege, and time(lessnes).

\section{THE NIGHT BOURSE: MARX AND VAMPIRIC CAPITALISM}

In Capital, Marx and Engels make explicit references to the connection between vampirism and capitalism in their analysis and critique of what we could call the horror of capitalism. While the text ostensibly addresses two main types of horror - the first being the capitalistic legislation against vagrancy, the second being the capitalistic horrors of colonialism - Mark Neocleous (2003) suggests it also latently points to a third type of horror namely "the constant sucking of the blood of the Western working class by the bourgeois class. This form is nothing less than the horror of a property-owning class that appears to be vampire-like in its desire and ability to suck the life out of the working class" (Neocleous 2003, p. 668). Marx and Engels make several explicit references in the text that elide vampirism and capitalism: "Capital is dead labour, that, vampire-like, only lives by sucking living labour, and lives the more, the more labour it sucks"; "the prolongation of the working-day beyond the limits of the natural day, into the night, only acts as a palliative. It quenches only in a slight degree the vampire thirst for the living blood of labour"; "the bargain concluded, it is discovered that he was no 'free agent,' that the time for which he is free to sell his labour-power is the time for which he is forced to sell it, that in fact the vampire will not lose its hold on him 'so long as there is a muscle, a nerve, a drop of blood to be exploited"' (Marx 1867 [1976], p. 342, 367, 416). They also suggest that capital "sucks up the worker's value-creating power" and is dripping with blood, while also describing the appropriation of labour as the "life-blood of capitalism", while the state is said to have here and there interposed itself "as a barrier to the transformation of children's blood into capital” (Marx 1867 [1976], p. 716, 926, pp. 382, 1007).

Marx and Engels also outline the rudiments of the relationship between vampire capitalism and time in Capital. The authors specifically describe the elongation of the working day as a process of the vampirization, or turning, of the labour force into the nocturnal undead, whose bodies and the lives of those bodies become inextricable from capitalism's un-slakable thirst for more and more profit. In the chapter on the working day, Marx and Engels compare the historical development of the factory system with other historical forms of domination, such as Athenian aristocracy, Nor- 
man barons, American slave-owners and the feudal corvée. Regarding the latter, the authors note that the legal mechanisms through which peasants performed forced labour on behalf of landowners could be stretched well beyond the stated number of days. Using the example of Wallachian peasants performing forced labour on behalf of the Wallachian boyars, Marx and Engels note that: "for Moldavia the regulations are even stricter. 'The 12 corvée days of the Règlement organique,' cried a boyar, drunk with victory, 'amount to 365 days in the year"' (Marx 1867 [1976], p. 348). Marx takes this quote from É. Regnault's Histoire Politique et Sociale des Principautés Danubiennes (1855) in which the cited 'Wallachian boyar' is Vlad the Impaler: Vlad Dracula (Frayling 1991, p. 669-700).

In terms of class, it is a common trope in $20^{\text {th }}$ and $21^{\text {st }}$ Century Western cinema to present the figure of the vampire as a feudal aristocrat (Edmundson 1997, p. 20). Neocleous points to Franco Moretti's essay in which he develops a critique of Bram Stoker's Dracula (1897). In this influential essay, one which has subsequently come to impact the theorization of the concepts of capital-as-vampire and vampire-as-capital, Moretti discusses a dialectic of fear which rejects the feudal/aristocratic reading of Dracula as synecdochal of all vampires. Moretti argues that the more apt and accurate reading of Dracula characterizes him, and the figure of the vampire more generally, as representative of capital and a bourgeois class rather than land barony and the aristocracy. In this way, Moretti reads Dracula's insatiable desire/need for blood not as representative of the aristocratic class and its desire to maintain the tight concentric arrangements of its socioeconomic, supra-political, and pan-cultural wealth. Instead, he argues that this form of vampiric bloodlust is, in fact, a metaphor for capital's desire for accumulation. The inverse proportionality between Dracula, and vampires more broadly, and their victims is a powerful symbol of the necessarily exploitative relationship between capital and labour. While Dracula grows stronger the more blood he consumes, those living individuals which he drinks from grow weaker. Likewise, while capital grows and expands, the more exhaustive the demands placed on the labour-force become in order to not only attain, but accelerate said growth. It is for this reason that Moretti invokes Marx on the concept of capital-as-vampire in suggesting that "like capital, Dracula is impelled towards a continuous growth, an unlimited expansion of his domain: accumulation is inherent in his nature" (Moretti 1983, p. 90). Like the typically amoral and latently hedonistic 'evil', the on-screen vampires of global pop-culture oftentimes represent "sanguinary capitalism", "marauding figure[s] of unnaturally breeding capital, which penetrates every whole being 
and sucks it dry in the lusty production and vastly unequal accumulation of wealth", and vampire capitalism itself as a "capital that is not ashamed of itself" (Skal 1993, p. 159; Haraway 1997, p. 214-215; Moretti 1983, p. 91, 94).

Neocleous argues that Moretti's reading of Marx and vampirism is incomplete and can only be accomplished "by situating Marx's vampire metaphor in the context of his critique of political economy and, in particular, the political economy of the dead" (Neocleous 2003, p. 679). Relatedly but differently, I argue that Marx's vampire metaphor is most salient and robust when it takes into account the relationship between capitalism, vampirism, and time. So while Neocleus argues that "the way to understand Marx's vampire is less as a nineteenth-century cultural motif and more as an offshoot of Marx's preoccupation with the dead", I argue it is ultimately Marx's preoccupation with time that offers the most insightful and here relevant way of understanding the relationship between vampires, class, and capitalism (Neocleous 2003, p. 679). To be clear, Neocleous does also recognize the importance of the length of the working day as crucial in this regard, despite relegating it to ancillary support of his overarching reading of the importance of the relationship between living labour, dead labour, and the vampire. He notes that "in Capital this possibility of capital literally sucking the life out of the workers is fed into the paramount political question concerning the length of the working day. Capital, with its desire for endless and incessant accumulation, runs the risk of literally working the working class to death", not unlike a vampire with no measure or temperance in its desire to feed (Neocleous 2003, p. 681).

The reason I place an analytical premium on time over death is because death, as much as life is, ultimately a temporal phenomena. Therefore, the unnatural/supernatural circumvention of the limits of either phenomenological, ontological, and existential antipode - life and death - ultimately redound to the supernatural circumvention of the temporal constituent acting on all three categories of Being itself. The vampire, in this way, reveals that the ultimate form of capital is temporal in nature. When examined within the framework of the amount of time it takes for labour to convert resources into capital, for capital to circulate in an economy, and for that economy to sustain, exhaust, and ultimately terminate life, it is no surprise then that given the importance Marx attributes to the length of the working day, the figure of the vampire should appear as one of the central motifs in the chapter in Capital critiquing the working day. 


\section{THE ONLY LUXURY IS TIME: CAPITALISM, VAMPIRISM, THE PERFECT CONSUMER, AND TIME AS ULTIMATE RESOURCE}

According to Paul Kennedy, the specifically vampiric manifestation of late capital pertains to the fact that the "sector of capitalism which falls within the designation 'vampire' has reached the end of its useful life because it now disproportionately serves a tiny minority rather than humanity as a whole" (Kennedy 2017, p. 30). The latent suggestion here is that there is notable connective tissue between the figure of the vampire and the praxes of capitalism beyond the vampiric, that is exploitative, praxis of each in order to sustain themselves. The former refers to the capitalist manipulation of bodies, embodiedness, and the experience of time of said bodies. This is cognate with the vampire's supernatural ability to mesmerize, fascinate, and seduce its victims into a trance-like state. It is ultimately an affective state where the sovereignty of the victim's embodiedness is violated and their experience of touchstones of 'reality' as such, specifically time and space, are addled for the purpose of keeping said victim docile, submissive and therefore exploitable. This second strand, alongside or latent within the exploitative nature of each, is underpinned by the necessary importance of elitism, privilege, and exclusivity. The stratification of class, whether clearly perceptible in centralized social groups and institutions like the gentry, aristocracy, royalty, and mercantile classes in pre- and early industrial capitalism, or more surreptitious in the nebulous digitization of wealth and the obfuscatory deployment of 'anti-grind' culture by multi-national conglomerates like Amazon and/ or their variously dispersed ancillaries on and off-line, still persists in digital late capital. However, the exploitative class cannot maintain its various socioeconomic, sociopolitical, and cultural privileges in anything resembling an exclusive manner if the resources, both embodied and unprocessed, are distributed or shared equally. The exclusivity inherent to capitalist profiteering necessitates not only the necessarily disproportionate allocation of resources, but a disequilibrium of access to the means of production after the fact.

Interestingly, this exclusivity is everywhere present in contemporary cinema's depiction of vampires and their covens. Regardless of its presentation as base and countercultural, or elitist and sophisticated, it is brimming and always-already threatening to overflow from beneath the bloody surface of their soirees as it is in the blood rave that opens Stephen Norrington's s Blade, or their refined bearing and balletic deportment framed within the minimalism of advanced technology as it is in Len Wiseman's 
Underworld (2003). Being undead, vampires have the curse-privilege of existing in a state of exception, one predicated on Being outside of the regular flow and ravages of time. This exceptionality means vampires are, theoretically, potentially immune to the necessity of 'making use' of their time. There is no exigency of time because time for a vampire is unhinged from most mortal notions of lack seemingly inextricable from its own passing. The privilege of timelessness is a luxury that facilitates all others and, in this sense, vampires can be and remain the ultimate capitalist because of their embodied ownership of a resource that subtends and influences all others, namely time. Through immortality, barring the various albeit comparatively limited means of death conventional vampires are subject to, vampires have all the time to accrue knowledge, resources, wealth, and influence. They can be selective in their turning of influential individuals, appropriate their personal gifts and capital assets into the formation of an eternal elite, an echelon of exclusivity whose privilege of access and membership is determined by a supernatural imperviousness to time.

While both capitalism and vampirism are, by their nature, consumptive - that is, consuming bodies in the processes of production for the former, and more directly the lifeblood of mortals to remain active in the latter - the difference between capitalism and vampirism is that capitalism cannot continue consumptively forever. Its consumptive aptitude is limited to the resources and labour force it has to convert the former into capital. The total depletion of either will necessitate a cesura of consumption. Even without the blood of victims, vampires can remain dormant, inactively undead, until the earth is swallowed by the sun. If the "primary duty of capitalists is to seek and exploit market opportunities in the pursuit of maximum profits and as a central plank in the accumulation of capital" in which "caring first and foremost about the interests of those who have invested in a company", then "it follows that it cannot be the duty of, nor is it possible for, capital in general or of a particular business to develop national economies or overcome poverty per se" (Kennedy 2017, p. 30 ). Both capitalists and vampires require a simultaneously replenishable and readily available stock-of-bodies through, in, and by which to (re)produce, trade, accumulate, and store socioeconomic, sociopolitical, cultural, and ideological power. Without resources, labour, and/or time, both capitalists and vampires have to maintain a reproduction of specifically exploitable conditions wherein which their privilege, exclusivity, and power remain unchallenged and inaccessible.

However, if the privilege of the state of exception of being/non-being undead can be managed, obfuscated, occulted, and/or made exclusive, then the vampire becomes 
the symbol of an absolute capitalist or perfect consumer; namely, a consumer that can consume forever. In films like The Hunger, Underworld, and Interview With A Vampire, the ruling vampire aristocracy has in place very stringent rules, communal or idiosyncratic, about the exclusivity of not only being a vampire, but one of an established coven - many of which relate directly to sartorial practices, couture, fashionability, and style. This privileging, elitism, and exclusivity ultimately does not refer to wealth, influence, sociopolitical, economic, or cultural power but the time within which it takes to achieve, manufacture, and control said assets. I propose that within a Marxist framework of class struggle, the vampire is neither proletariat nor bourgeois but, on account of their supernatural onto-existential (non)being, represent a new class: the ex tempore class.

Fundamentally unlike their oligarchical and/or petrogarchical counterparts, many of which are shown to be vampires in the aforementioned cinematic vampire examples or shareholders in resource-based interests, be it gas, water, and/or electricity, the ex tempore class are tempogarchs who own private shares in timelessness. And this is where, comparatively speaking, capitalists and vampires differ most starkly. While the maximalist model of post-Industrial and late capital has produced sociopolitical, socioeconomic, cultural, and most harrowing in our experience of the Anthropocene, ecological crises that "are due to its unplanned success", the stringent rules of what we could call blood-rights in the fictive covens of contemporary pop-cultural vampires bespeaks a keen awareness of a hypersensitivity to the temperate maintenance of numbers in specific ratios. Here, there is a necessity of secrecy and measure in order for the ex tempore class and its 'the invisible power' to persist. In this way, vampires, again, are better, more robust, more ideal capitalists in that they all seemingly latently understand that despite the libidinal exigency of the 'thirst' (the desire to feed or literal blood-lust), they cannot consume and remain undead forever if they deplete the source of their undead lives beyond simple eternal existence, their lifeblood, which is, oftentimes literally the blood of the living. Here, a seemingly cliched balance (re)asserts itself: there can be no (un)death without life. 


\section{DARK GLAMOUR, OR VAMPIRES WEAR YVES SAINT LAURENT: ON THE HUNGER, FASHION, SEX, POWER, DEATH, AND TIME}

\section{Figure 2}

The Dark Elegance of Miriam Blaylock in Tony Scott's The Hunger (1983).

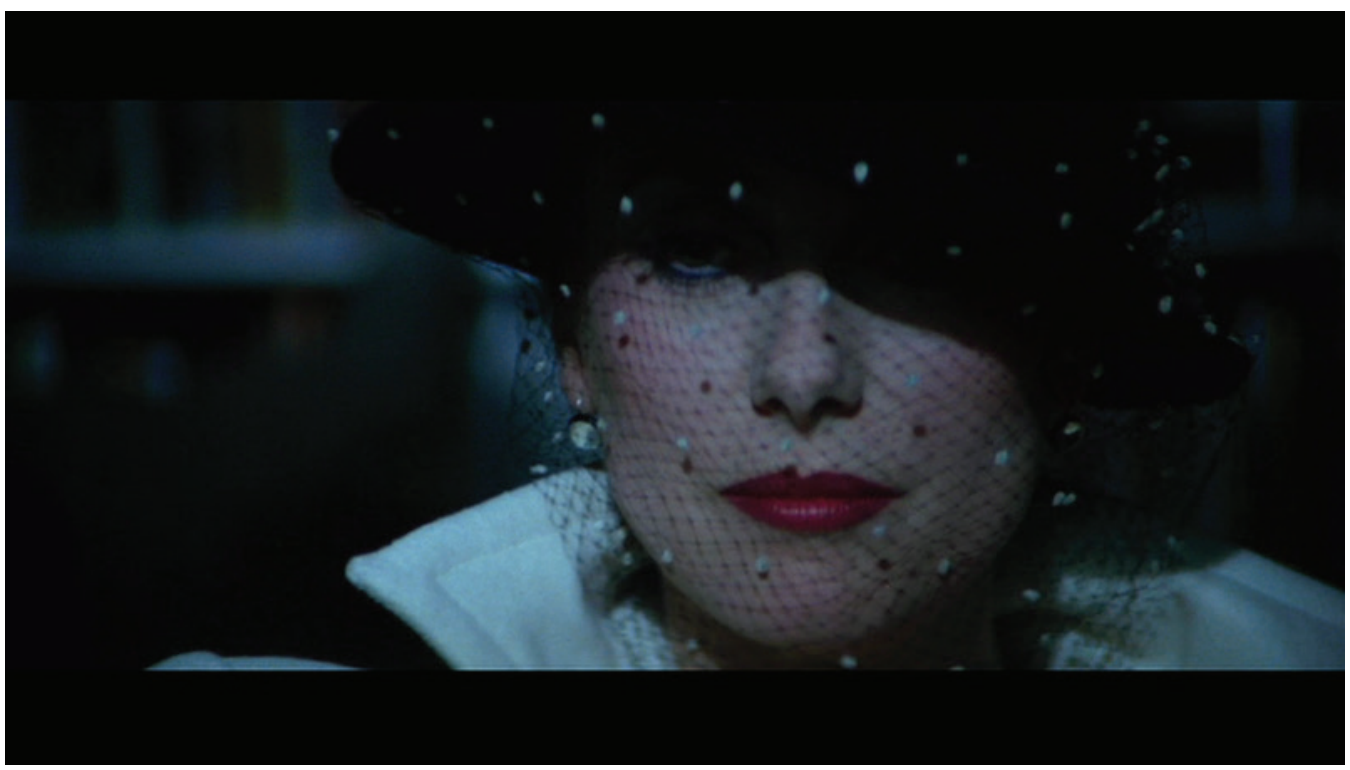

Tony Scott's 1983 directorial debut is an erotic horror whose narrative centres on a love triangle between a vampire couple, Miriam and John Blaylock (Catherine Deneuve and David Bowie) and a sleep and aging specialist, Sarah Roberts (Susan Sarandon). In an opening flashback, the viewer witnesses Miraim in ancient Egypt, draining victims of their blood, promising specifically selected lovers the gift-curse of eternal life. John, her companion in the film's present, is a talented cellist whom she turned in $18^{\text {th }}$ Century France. The first indication of the affluence and class status held by the couple occurs early on in the film where the couple scout for victims in a chic underground New York nightclub. Donning stylish black leather slim-fitting attire, exuding undeniable sex-appeal, danger, and quiet command, the couple oversee the revellers and the dancers in the intimate Neo-Gothic atmosphere as if a lord and lady surveying fruit at a peasant's well-made weekend market. After selecting, seducing, and exsanguinating a couple, their bodies are disposed of in an incinerator in the basement of the couple's extremely large and elegant New York townhouse. While 
their cover as a wealthy couple who teach music may be spurious, the wealth they possess is not. It is announced and symbolized in every aesthetic aspect of the film: from their respective takes on Bauhaus post-punk chic, replete with the accenting of their nocturnal attire - typically black, leather, finely cut, and/or laced - with cat-eye sunglasses, to the opulence and refinement of their interior decoration whose Doric pillars, flowing drapery, and marble walls at once feel out-of-time and timeless.

The Hunger is also a particularly pertinent text in the remit of this article's discussion due to its focus on not only vampirism as a type of exclusive wealth, but also that wealth and exclusivity's relationship with time. In the film, John begins to suffer acute insomnia and begins rapidly aging in the space of a few days. While being 200 hundred years old, it is revealed that Miriam's promise of immortality included a specific caveat; namely, that while the periodic feeding on the lifeblood of victims would grant him everlasting (un)life, it would not proffer him with eternal youth. In his desperation, John seeks out Dr. Roberts, a gerontologist, specializing in the effects of rapid aging in primates. After initially dismissing his pleas as eccentricities and the products of mental instability, she eventually sees the physical effects of his rapid aging and agrees to help him, which results in John rebuffing her aid. In a final effort to regain his youth in his eternal life, John kills and drains one of his students, Alice Cavender (Beth Ehlers, note the seeming pun on the word cadaver and the name 'Cavender'), whom, it is revealed, Miriam had been grooming to replace John as her next lover and partner-in-time. Having no effect, the desperate John begs Miriam to kill him and release him from the agony of his decrepitude. She tells him there is no release and carries his body after he collapses to the attic of their castle-like town house, where Miriam deposits his body in a coffin surrounded by a multitude of others in which Miriam's former lovers throughout time sleep undead. The scene is pierced with the lamentations and moaning of the eternal living dead trapped in said coffins, unstuck in time yet granted no power thereby. 


\section{Figure 3}

The Haute Couture Chic of Miriam Blaylock in Tony Scott's The Hunger (1983).

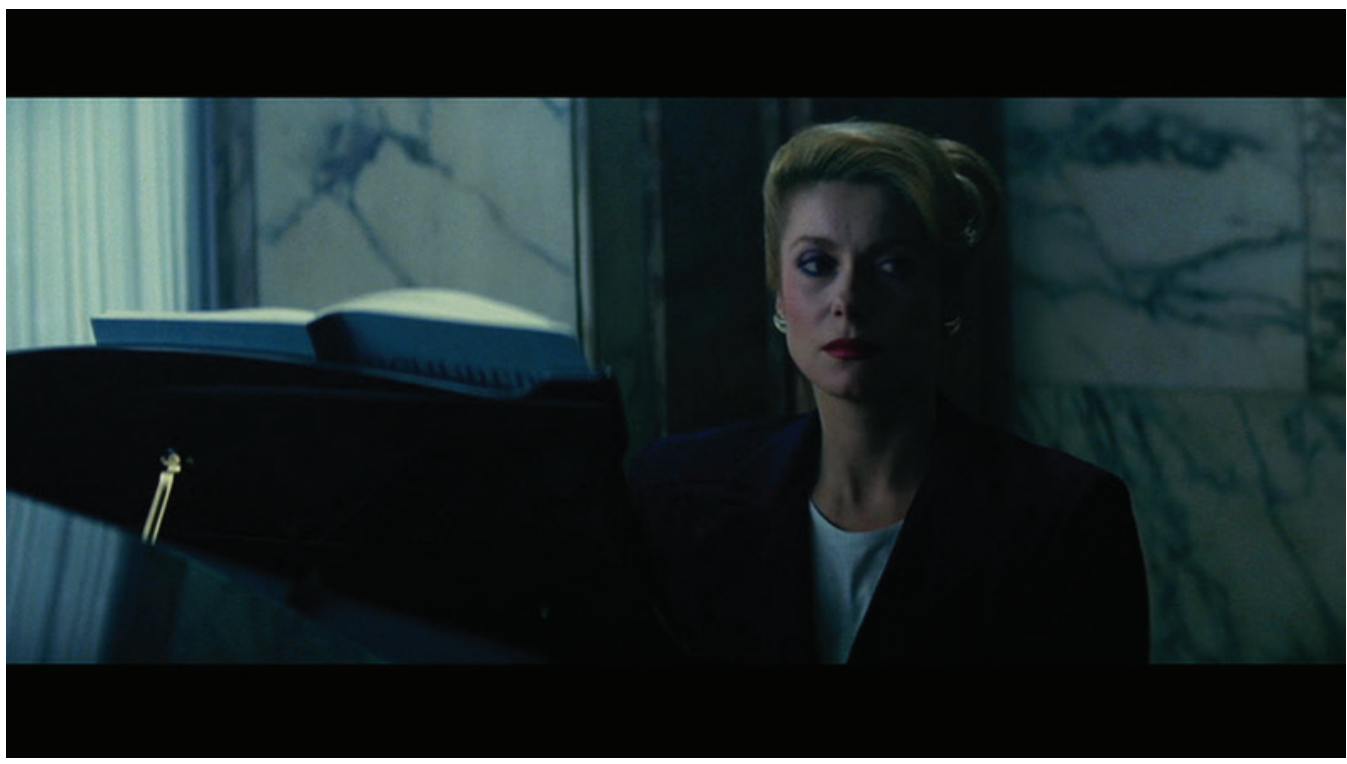

The film's dark glamour is in no small part the result of the fact that its costume and location aesthetic is determined and influenced by such luminaries of style as Cristobal Balenciaga and Yves Saint Laurent. In fact, the film was screened in 2013 at the Cristobal Balneciaga Museum in Spain in recognition of the film's supremely elegant portrayal of power, privilege, fashion, sex, death, and immortality in a retrospective commemorating the famous fashion designers who contributed to film more broadly (n.a 2013). There are interesting aspects of production regarding attention to detail in the film that make inextricable the link between vampirism, capital affluence, sophistication, finery, and privilege that reflect the privilege-of-time central to the film's narrative. For example, Irenebrination notes how

one of the most respected costume designers around, Milena Canonero (who turned to the Tirelli tailoring house to find the historical costumes for some of the scenes included in the film and even sourced in Italy the proper material to put in the top pocket of David Bowie's beige suit as she couldn't find it in London), while Catherine Deneuve's wardrobe was by Yves Saint Laurent (also worth mentioning the special effects by Graham Longhurst; makeup illusions 
by Dick Smith and special makeup by the late Anthony Clavet, who worked a lot for Italian Vogue). (n.a 2013)

\section{Figure 4}

The Style, Wit, and Class of Miriam Blaylock in Tony Scott's The Hunger (1983).

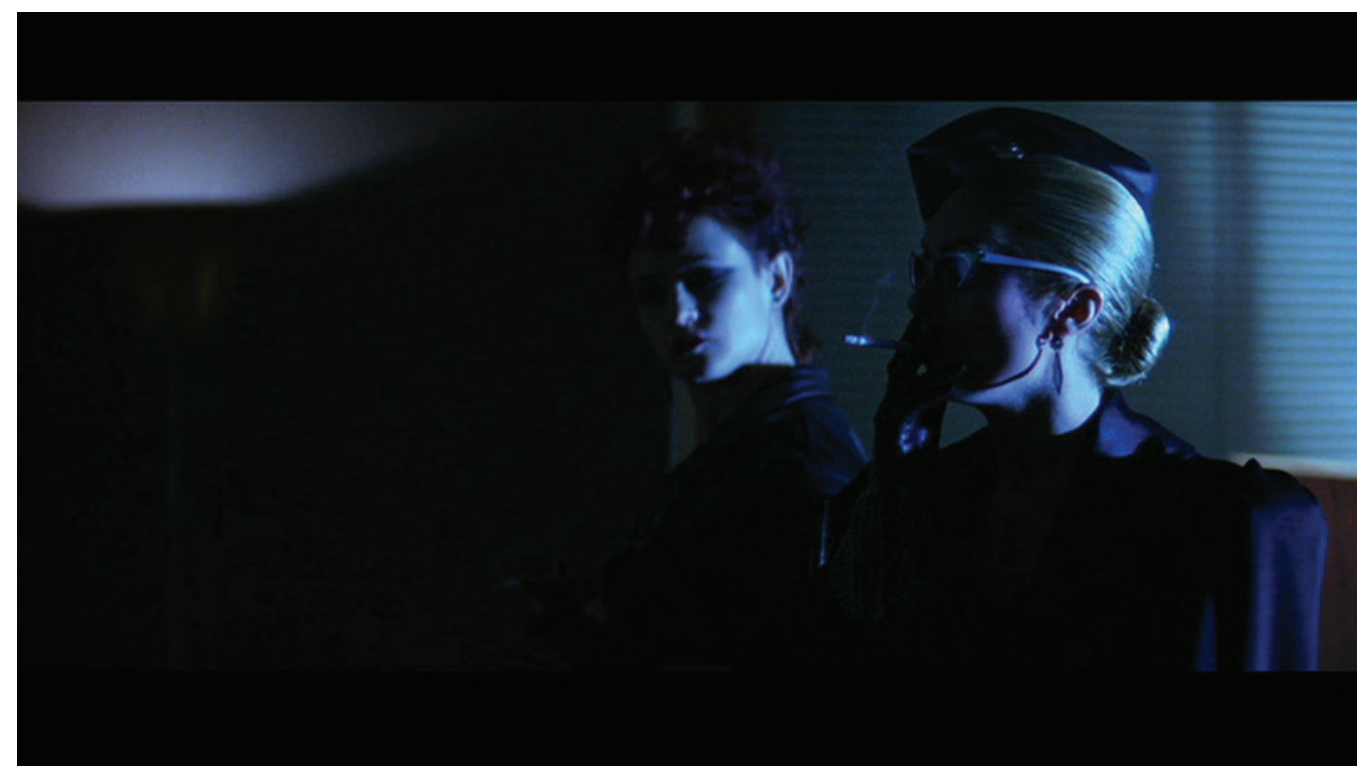

Indeed, the film's themes of love, passion, loyalty (to the brand, the brand in this case being that of the chic vampire), sexual desire, and most concertedly, the fear of death, can all be theorized from a fashion perspective. "While fashion never dies but constantly resurrects itself season after season", notes Irenebrination "quite often fashion houses keep on being alive even when their founders die or are revamped a few decades after their deaths. Besides, current fashion is also displaying a vampirical desire for more and more runways and more and more customers" (n.a 2013). Similarly, not only does the brand of Laurent share a long collaborative history with Deneuve herself, but the pairing of the two reflects not only the sense of traditionalism and refinement central to her character in the film, but that character's totemic modernization of the aristocratic be-fanged and caped Eastern European coffin-riding vampiric forbears. In the same way the vampire represents the embodiment of capital's undead blood-lust, mesmeric fetishization of wealth and affluence, and exploitative violence, Miram represents the refinement of the vampire and everything about the figure 
that appeals to modern audiences: socioeconomic and cultural power, sophistication, temporal largesse, sexual appeal and kraft or force, and an undeniable, violent, and morally opaque desirability. The Count, a consumer of feudal labour, becomes a fashionista, a consumer of high fashion. "She is elegant, enigmatic, and stylish" writes Irenebrination, "and lives surrounded by rare art pieces in a beautiful house in New York in which lights create mesmerisingly sensual yet scary chiaroscuro effects; Saint Laurent's designs had a timeless quality about them [...] and are perfect to hint at the vampire's glamorous immortality" (n.a 2013).

Inherent in this modernization is an updating of the symbols of the power allotted those supernaturally endowed with temporal capital. The castle becomes a chic New York townhouse so that what was once removed and rarefied - even decrepit, as is the case of Lugosi's Dracula's castle - becomes an elegantly refined, smaller, albeit manor-rich property. It is at once contemporary but also museum-like in its collection of the numerous examples of finery through the various periods of antiquity unnaturally lived through and as such a rejection of the staticity of primogenitureproduced palaces whose chief sense of character emerges now only as a Gothic cliche in the collective imagination of the modern audience. Far from the dark moonlit moors and wind-wuthered heaths in dun dells and stark countrysides, these modern castles appear in the paradoxically rarefied upper-class areas and neighbourhoods of bustling centres of commerce where a wealth of socioeconomic capital and human capital in the form of potential victims freely circulate. The couture of the Count, with its stiff high collars, starched shirts and frocks, and equally clean and velvet-lined coffin-dusty capes is stripped down, and now takes on the elegant minimalism of haute couture; wide lapels, sumptuous fabrics in muted shades, and carefully chosen demure-cum-ostentatious mercantile accessories of finery mock the traditional fear of the sun, symbolized by the droll albeit stylistic irony of wearing sunglasses at night. Lastly, and perhaps most importantly, while the Count's traditional symbols of power are steeped in the obfuscatory effect engendered by the combination of the supernatural, mysticism, and the Judeo-Christian fear/intolerance thereof that act as a combined force that Others and abjectifies the figure of the traditional Gothic vampire, the contemporary vampire maintains the privilege of its abjection. It does so by safeguarding its paradoxical periphery centrality within mortal society primarily through the accrual of capital, and the socioeconomic, sociopolitical, and cultural distance wealth can purchase and purchase with style. 


\section{GLOAMING: CONCLUSION}

This article has attempted to draw attention to a latent aesthetic and narrative element in the contemporary history of $20^{\text {th }}$ and $21^{\text {st }}$ Century pop and visual culture's multi-media representation of the figure of the vampire. This element, namely time, is, by virtue of the fact of its thematic nativity to vampires and vampirism, often taken for granted. The above analysis has attempted to establish and renew lines of flight and critical interest in the triadic relationship between time, monstrosity, and class, as well as the notion of privilege that subtends each of their relations with one another. It has hypothesized that there is an inextricable link between the privilege of the vampire, afforded by its un- or supernatural monstrosity, which ultimately redounds to a supra-temporal onto-existential condition, and capitalism. While the figure of the vampire has historically been represented as a totem of various approaches to privilege and aristocratic elitism through both physical and pecuniary endowments (typically vampires are strong and rich), the above investigation discovered that the direct result of these phenomena is a state of exception which, among other things, fundamentally reframes the figure of the vampire in socioeconomic terms; from psychospiritual monster to perfect capitalist consumer whose immortality ultimately means that the figure of the vampire can consume without end. This article also acknowledges that one could argue that its discussion of time and class could be reterritorialized within an argument concerning time and status. This is because the relationship between aristocratic privilege and time is contrapuntal to the capitalist relationship with time. The former is entirely predicated on leisure, taken to be a right or primogeniture-guarenteed endowment. Leisure, as a remove or alienation from the rigours of work, is, in many ways, the aristocrat's wealth or at the very least, a significant aspect thereof. In this sense, aristocratic wealth as time unmarked by work is not necessarily inextricable from money. Without it, the aristocrat still holds herself to be privileged, by blood and title, as exceptional. Engaging in work for whatever purpose is what ultimately countermands that state of exception. This relates to vampirism as represented in Western horror cinema in that whether street, gutter, or sewer dwellers as are David (Kiefer Sutherland) and his lost boys in The Lost Boys or Nomak (Luke Goss) and his Reapers in Guillermo Del Toro's Blade II, or the bohemian chic of Eve (Tilda Swinton) in Jim Jarmusch's Only Lovers Left Alive (2013) or the corporate chic of the Spierig Brother's vampire businessmen in Daybreakers (2010), all are ultimately undifferentiated by being exempt from experiencing the flow of time in the 
way humans do. In this sense, the onto-existential reality of being a vampire is more fundamental than the socioeconomic status and/or class that rests upon it, regardless of whether that individual vampire be fashionista or flea-ridden. In the last instance, the aristocratic vampire and the proletariat vampire are equally as rich-in-time by being exempt from it. The latter, however, causes new categories of temporal privilege to emerge. From it arise the bourgeois and the industrialist both of whom are enriched, not denigrated, by work. While guided by the logic of production and profit, the industrialist vampirizes the work of her labourers, which ultimately occurs in time, thereby exploiting mortal time to sate the immortal appetite of capital. This suggests that the ultimate expression of the above analysis in terms of the idea of infinite consumption is that such a phenomenon would necessarily rely on infinite resources, one, in particular: time. A vampire labour-force could, once having exhausted the resources of their particular village, nation, continent, and planet, move on to others, vampirizing entire worlds by and through the true wealth, privilege, and power they possess, namely, their exemption from the degenerative effects of time.

\section{REFERENCES}

Edmundson, M. (1997). Nightmare on Main Street: Angels, Sadomasochism, and the Culture of Gothic. Cambridge, Massachusetts: Harvard University Press.

Frayling, C. (1992). Vampyres: Lord Byron to Count Dracula. London: Faber and Faber.

Haraway, D. (1997).Modest_Witness@Second_Millennium.FemaleMan_Meets_Onco Mouse $^{\mathrm{rm}}$ :Feminism and Technoscience. New York: Routledge.

Kennedy, P. (2017). Vampire Capitalism: Fractured Societies and Alternative Futures. London: Palgrave Macmillan.

Marx, M. (1867 [1976]). Capital: A Critique of Political Economy, Volume 1 (1867), trans. Ben Fowkes. Harmondsworth: Penguin.

Moretti, F. (1983). Signs Taken for Wonders: Essays in the Sociology of Literary Forms. London: Verso. 
Neocleous, M. (2003). The Political Economy of the Dead: Marx's Vampires, History of Political Thought, 14(4), 668-684.

Skal, D. J. (1993). The Monster Show: A Cultural History of Horror. New York: Farrar, Straus, and Giroux.

Strieber, W. (1983). The Hunger. Directed by Tony Scott. Los Angeles: MetroGoldwyn-Mayer.

n.a. (2013, July). "Vampires Wear Yves Saint Laurent: Tony Scott's The Hunger@ the Cristobal Balenciaga Museum." Irenebrination: Notes on Architecture, Art, Fashion, Fashion Law \& Technology. https://www.irenebrination.com/ irenebrination_notes_on_a/2013/07/the-hunger-balenciaga-museum.html 